\title{
A török viseleti darabok hatása hazánkban a hódoltság korában
}

\section{Effect of Turkish Traditional Costumes on Our Country During Occupation}

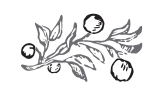

\section{Összefoglalás}

A magyarság öltözetét a Kárpát-medencében való letelepedés óta keleti és nyugati hatások is érték. Minden társadalomnak és történelmi kornak megvolt a divatja, ez sokszor befolyásolta a népviseletet. A hódoltság hosszú időszaka jelentős nyomot hagyott valamennyi társadalmi csoport öltözködésének alakulásában. A tanulmány mindezek írott emlékeit mutatja be, nemenként és társadalmi rétegenként rendszerezve a fellelhetô forrásokat.

Kulcsszavak: kora újkor, török hódoltság korszaka, kereskedelem, magyar népmúvészet, magyar népviselet

\section{Summary}

Value of the Hungarian clothing have been effected by the East and West since the settlement in the Carpathian Basin. Every society and historical era had its fashion, this is often influenced the traditional costumes. The long period of occupation left a significant mark in a development of dressing among all social groups. The study

Dr. Vehrer AdéL PhD, egyetemi docens, Széchenyi István Egyetem Apáczai Csere János Kar (vehreradel@gmail.com). 
shows the written memories of all these the available resources are organized by gender and society.

Keywords: in early modern era, era of ottoman thraldom, commerce, Hungarian folk art, Hungarian traditional costumes

A hódoltság korában a magyar népmúvészetet erôteljes török hatások érték. Az ország török uralom alá kerülése a kereskedelemben is fordulópontot jelentett. A változásokat a hivatalos egykori feljegyzések bizonyítják. Az akkori viselet rekonstruálásához nélkülözhetetlenek a korabeli vámnaplók és számadáskönyvek. A megmaradt múzeumi darabok előkelő törökök ajándékaiból, hadizsákmányból, Magyarországon dolgozó török rabnők munkáiból származnak (a magyar úri házaknál török varróasszonyok dolgoztak), de többségük török hatásra készült magyar textilfajta.

A törökös formakincs a 16-17. században kezdett érvényesülni a Magyarországon készített hímzéseken. A legtöbb török vagy törökös hímzés a református egyházak úrasztali takarói, kehely- és kenyérborító kendôi között maradt fenn. Akad olyan is köztük, amelyikbe belehímezték, melyik csatában zsákmányolta a harcos, aki azután az egyháznak ajándékozta. Ezekkel a hímzésekkel a parasztság is megismerkedhetett, motívumaikat, szerkesztési módjukat utánozhatta. A felsoroltakon kívül kályhacsempéken is ábrázoltak viseletes embereket. A források tanúsítják, hogy a magyarok ebben a másfél évszázadban kedvelték meg a színes, csillogó török holmit: a selyemkaftánokat, az aranyhímzésú kendôket, nyergeket, lótakarókat, fegyvereket, szőnyegeket és a cserépedényeket (Domanovszky, 1981:73-76; Fél-Hofer-K. Csilléry 1969:45-47).

A sokféle felszerelésen kívül a török textíliák kerültek legkorábban és legnagyobb számban a magyarok tulajdonába. Egyrészt hadi és diplomáciai érintkezés útján jutottak be hazánkba, másrészt a rendszeres kereskedelem is közvetített nyersanyagot vagy belőle készített ruhanemút és egyéb háztartási cikkeket. A rendelkezésre álló forrásanyag alapján, a 16. század közepétôl kísérhetjük nyomon azoknak a portékáknak a beáramlását, amelyek alapvetốn meghatározták a viselet és az öltözködés lehetôségeit. Az árucikkek tömeges behozatalát a hódoltság idején az is megnövelte, hogy a nagy számban itt élố török polgári lakosság szükségleteit ki kellett elégíteni. A török áru beáramlása Erdélyben volt a legintenzívebb, de van számos példa arra is, hogy török kereskedők az Alföldön bonyolítottak le nagy forgalmat (Palotai, 1940; Novák, 1982).

A hódoltság idején hatalmas árumennyiség érkezett Pestre, mégpedig hajón, a Török Birodalom balkáni és ázsiai területeirôl. Az 1550 és 1580 közötti idôszakból ismert budai török számadáskönyvek részletesen feltárják az áruféleségek sokaságát: nagy mennyiségú juh- és marhabőr, talpbőr és szattyán érkezett, ezenkívül különféle ruhaalapanyagok, ritkábban ruhadarabok. A török kincstári számadáskönyvek tanúsága szerint a kereskedelmi tevékenység két színtéren zajlott: egyrészt a dunai kikötő (iszkele) fogadta be a hajón érkezô árut, másrészt a városkapukon át érkezô kereskedôket 
tekinthette át a vámos. Hogy a portéka külföldrôl vagy török belföldrôl érkezett-e, azt a jegyzékben ritkán tüntették fel (Novák, 1982; Fekete-Káldy-Nagy, 1962:553).

A vámnaplókban a következó textilfélék szerepelnek: damaszt, atlasz, selyemszövet, selyem, gyapot, török fonál, vánkoshéj, perzsa fonál, selyemfüggöny, szônyeg, kecskeszốr fonal és abaposztó (Palotay, 1940). A számadáskönyvek adataival kiegészítve: filc, pokróc, kebe, pamut, vászon, gyapotfonal, boszniai ruhanemú, mesin, fehér kurta köpeny, jorgan, kaba, juhpasztoma, bunda és a süveg különbözó típusai fordultak meg a kikötőkben. A posztóféleségek széles skáláját ismerjük: aba, bagazsia, boroszlói, csuha, csuka, dimi, igler, istamád, karazia, kisznicser, norimbergi, szoberman és vereszit. A fehérnemúk, a nối ruhának való vásznak, a lenfélék és a kirbasznak nevezett vásznak egy része török volt. Az egyik legkeresettebb árucikk a süveg volt, állandóan és nagy mennyiségben hozták. A forgalom a kül- és belhoni ruhanemú között 80:140 arányt mutatott, kizárólag belföldi eredetúnek csak a bőrök, prémek és lábbelik tekinthetôk (Novák, 1982).

A magyar nép ekkor ismerte meg a különféle bôrfajtákat, amelyre jövevényszavaink is utalnak: papucs, csizma, szattyán, kordován, mesin, csizmadia, dikics és csiriz. Az említett ruhafélék, anyagok nagy részét értékesítették Budán. A török belföldról többnyire dunai hajókon Budára érkezố ruhanemú mennyisége több volt, mint amennyit az itteni lakosság igényelt, ezért egy része továbbment Nyugatra. Akik gyakran megfordultak a török közigazgatási székhelyen, ott vásárolták meg a szükséges, otthon be nem szerezhetố cikkeket (Novák, 1982; Fekete-Káldy-Nagy, 1962:572-681).

A falvakat járó, szekerezô és gyalogos közvetító kereskedôk vidékre is eljuttatták a távoli manufaktúrák és gyárak termékeit. Bosnyák és török árusoktól lehetett beszerezni például a keretezett tükröket, különféle gyöngyöket, nyakláncokat és a piperecikkeket. A városok társadalmának jellegzetes rétegét alkották a kézmúvesek és a kereskedôk. A mezóvárosi fejlődés meghatározói voltak, hiszen ók biztosították a gazdasági vérkeringést, és olyan fontos áruféleségekkel látták el a lakosságot, mint például a ruhanemú vagy a fényúzési cikkek. (Novák, 1986:105-107; Hofer-Fél, 1975:28) Kecskemét vásárai messze földön híresek voltak, mert rengetegféle külföldi portékát árusítottak a keleti országok kereskedői. A környékbeliek másutt nem juthattak hozzá a gyolcs, patyolat selyemkendôkhöz, abaposztóhoz vagy karmazsinbőrhöz, kizárólag a kecskeméti vásárban, és csak török kereskedóktôl tudták megvenni. A források szerint még a nagykôrösi városi tanács is itt vásárolta a törököktôl a bôrárut (Balanyi, 1868:109-111).

Nemcsak keleti kereskedók foglalkoztak török áruk behozatalával a hódoltsági területen kívül esố helyekre. A régi feljegyzésekben gyakran szereplô török áros elnevezés nem feltétlenül a kereskedô török származására utal, hanem inkább portékájának török eredetét jelenthette. Kassán például 1587-ben említik, milyen típusú árut vásárolták a török áros Nagy Imréhtől, aki magyar ember volt. 1624-ben Paxy János nagyszombati magyar kereskedô a következó árukat hozta Komáromba: abaposztó, rácz takaró, abaköpeny, bagazsia, selyemtakaró, selyemzsinór, pamut, patyolat, szônyeg, karmazsin, asszonyi öv, cérna, nôi szövet stb. Ezekrôl a vámlevél megjegyzi, hogy mind török áru. 1559 óta hasonló árucikkek szerepeltek a kereskedôk útleveleiben. A lel- 
tárak azt is alátámasztják, hogy a régi magyar úri háztartásban milyen széleskörúen használták fel a török anyagokat a ruházati és a háztartási fehérnemúk között. Rimay János portai követ vásárlásainak jegyzékéből nemcsak az túnik ki, hogy milyen török vászonfélék voltak akkoriban kaphatók Konstantinápolyban, hanem az is, hogy itthoni használatra, a magyar ember számára melyek látszottak alkalmasnak (Palotay, 1940).

Elsôsorban a legdíszesebb anyagú és jellegzetes keleti szabású felsôruhát, a kaftánt kedvelték hazánkban. Gyakran zsákmányként vagy a hadviseléssel együtt járó rablás révén jutottak hozzá. A török-magyar együttélést és a múvelődési javak kicserélődését bizonyítja, hogy a budai pasák révén ajándékként is kerültek török ruhadarabok a magyar urak kezébe. Egy Ali nevú budai pasa 1606-ban például Mátyás fôhercegnek küldött egy szép aranyos kaftánt (Palotay, 1940; Takáts, 1928:518). Zrínyi Miklós, a szigetvári hôs is sok és díszes mentét kapott a törököktôl. Ifj. Rákóczi György fejedelemmé választásakor a szokásos beiktató ünnepélyen a pasa, a szultán levelének átadása után, kaftánokat adott az ifjú fejedelemnek. Bethlen Farkas, aki 1678-ban több erdélyi fơúrral Konstantinápolyban járt követségben, elégedetlen volt a nagyvezér részéról való barátságtalan fogadtatással. Azt panaszolta hazaküldött levelében, hogy nem kaptak kaftánt.

A kaftánokon kívül még másfajta, nálunk használt török ruhafélékrôl is van tudomásunk, a források a török zubbonyt és a cselebi mentét is említik. Ezek a ruhafélék törökös elnevezéseiket valószínúleg anyagukról nyerték, bár az is biztos, hogy a török formák, szabásmódok is átalakították a magyar öltözködést, különösen a férfiak ruháit. Az adatok szerint több volt a feldolgozatlan textilanyag behozatala hazánkba, mint a kész ruháké. Az anyagok Erdélybe és Magyarországra való eljuttatása a hódoltság idején rendszeres és virágzó kereskedelmi tevékenység volt, amit az is bizonyít, hogy Bethlen Gábor 1621-ben kiadta a Török, Görög és Sidó Kereskedôktól behozandó Marhák limitatióját. Ebben nagyon sok Törökországból behozott textilfélét megemlít. Az árszabás elôírja, hogy milyen anyag, kinek és mennyiért adható el, valamint megszabja a textíliák árát szín és fajta szerint is (Takáts, 1928:518).

A korabeli hagyatéki leltárakból tudjuk, hogy a török ruhaanyagok nemcsak a nagyúri osztály, hanem a polgárság körében is korán elterjedtek. A rendelkezésünkre álló adatokból az is kitúnik, hogy a rendkívül drága, arannyal-ezüsttel átszôtt brokátok nem szerepeltek kereskedelmi forgalomban, de a leltárak szerint a förangúak birtokában általánosak voltak. Valószínú, hogy az ilyen értékes portéka, mivel nem volt mindennapi keresleti cikk, csak rendelés útján került a magasabb társadalmi rétegek birtokába, vagy portai megbízottaikkal vásároltatták ezeket Konstantinápolyban (Palotay, 1940).

A ruházkodáshoz szükséges anyagféleségek többségét részben helyben, részben pedig fontosabb kereskedelmi központokban, például Pesten szerezték be a magyar mezôvárosok lakói. A ruhák anyaga többnyire könnyú volt, a keleti viseleteket utánozta. Kedvelték a színes szöveteket, feketét nagyon ritkán, szinte kizárólag csak gyászban viseltek (Novák, 1982). Külföldi írók emlegetik, hogy a papok hosszú, vörös ruhában jártak. A szegényebbek viselete az úri ruházattól többnyire csak anyagában különbözött: ami a felsôbb osztálybelieknél selyemból, bársonyból és finom posztóból készült, 
azt a szegények darócból, karasiából, szúrposztóból, durva vászonból (ezt többnyire házilag festették, és bagazsiának nevezték) készítették (Höllrigl, 1991:357-387). A tanácsbeliek fehér ruhát, köpönyeget viseltek, amely fehér (hamuszínû) abából készült, és gombok helyett kapcsok díszítették. Hozzá fekete süveget és sarkantyú nélküli csizmát illett felvenni (Balla, 1856). A köznép általában abaposztót viselt, gombok és zsinórok nélkül, helyette kapcsokat használtak, hozzá a csizma és süveg járt, bár a cselédek bocskort hordtak. A jobb módúak is abából viselték a dolmányt, nadrágot és köpönyeget, hiszen az aba akkoriban általános textilféle volt. Hornyik szerint a cselédek, szolgák és mezei munkások inkább szúrt, subát és ködmönt hordtak. Az előkelô emberek kisznicér, fajlangis és karazsia kelmébôl viselték öltönyeiket (Hornyik, 1861).

Csányi János, Kecskemét egykori fơbírája így jellemezte a korabeli öltözetet: a gazdaemberek általában aba, azaz fehérposztó mentét hordtak fekete bársonyprémmel, fehér nadrággal és kerek, magas szôrsüveggel. Az alsóbb osztályú férfiak és szolgák nadrág helyett bô nadrágformára maguk által összevarrt és szôrével kifordított juhbôrt hordtak. Érdekes ruhadarab volt még a kacagány, amikor egy nagy ürüjuhbôrt a nyakán kétfelé hasítottak, és ennél fogva a nyakukba kötötték. Papp László szerint ugyanakkor nem volt ekkora különbség az egyes rétegek viselete között (Papp, 1930: 14-46).

A török viseleti kultúra hatására újabb szegedi iparágak is kibontakoztak, mint például a papucsos- vagy a gombkötôszakma. Ezek eleinte nyilván a betelepült török lakosságnak dolgoztak. E kultúra hatásának nyomaira bukkanhatunk a 18. századi szegedi iratokban, végrendeletekben például a következô szavak szerepelnek: bujavászon (hímzett török vászonkelme), csalma (tatársüveg), skófium (hímzőfonal), töröking, törökkordovány, törökpapucs, törökszônyeg, törökzsinór (Bálint, 1968:88-112).

A 18. századi tanácsülési jegyzókönyvek és végrendeletek tanúsítják, hogy a kisgazdák és iparos-kereskedő elemek rétegétől felfelé majdnem mindenki rendelkezett ezüsttárgyakkal, elsôsorban a tisztességes öltözet elengedhetetlen kiegészítőivel, kapcsokkal és pártaövekkel. Az adók részeként rengeteg holmi vándorolt törökhöz és magyarhoz egyaránt. A cívis fényúzés az öltözködés területén is megnyilvánult. A kecskeméti tanácsülési jegyzőkönyvek peres iratai drága, szép öltözeteket említenek: Bakos Erzsébet a marhák árát „drága öltözetekre, magára és leányára költötte, amint ládabeli ruhákból meg is tetszik”. Szabó János egy árvát „mint atyjafiát drága szép öltözetekben járatta”. Érdekes módon a vagyongyújtés és a fényúzés nem terjed ki a keleti szônyegek divatjára, pedig sokat láthattak belőlük, mivel Kecskemét és Nagykőrös városok vásárlásaiban állandó tételként szerepelnek az ajándékozásra szánt szőnyegek (Bobrovszky, 1980).

A fennmaradt töredékes 17. századi kecskeméti egyházgondnoki számadások nem említik török tárgyak meglétét a református egyházban. Mivel a jellegzetes török luxustárgyak birtoklása veszélyt jelentett, sem a mezóvárosi polgárok, sem az egyházak nem vásároltak ilyeneket. Ezzel szemben a debreceni hagyatékokban már a század elsố felében szónyeg, kilim és kaftán is előfordul. Veszélyes tett volt, mert aki a törökhöz húzott (törökösséggel vádolták), azt halállal büntették. A Próféta színeibe öltözködôk is számíthattak a megtorlásra, aki pedig turbánt próbált a fejére, erôszakkal törökké 
tétetett. A hódoltságban élóket abban viszont nem akadályozhatták meg, hogy ötleteket, motívumokat, technikákat vegyenek át (Bobrovszky, 1980).

Kecskeméten és Kőrösön általában az volt a gyakorlat, hogy a finom textil- és bôrárukat Budán, Pesten vagy Szegeden szerezték be, zsidó vagy török kereskedôktól. Egyik legkedveltebb ruhadarabjuk volt a török eredetú kürdi nevú ujjatlan mellény, amelyet aztán saját igényeiknek megfelelően átalakítottak. A komjáti kánonok tiltották a török módra nyírt hajat, illetve a piros és más, világos színú csizmák viselését. Nôknek egyáltalán nem engedélyezték a csizmát. A parasztvárosi fényúzés azonban elsôsorban a ruházkodásban nyilvánult meg. A cívispolgár tekintélyéhez feltétlenül hozzátartozott a családtagok szép öltözete, amelynek fényét fóleg az ezüst ruhadíszek emelték (Bobrovszky, 1980).

\section{FÉRFIVISELET}

A férfiruhák gránát, csimazija, májszer, karasija, rása, sztamét és aba elnevezésû szövetekből, posztókból és különféle prémekból készültek. A kisznicér és karazsia vörös, kék vagy zöld lehetett (illetve ezek árnyalatai), a fehér karazsiát már ritkábban vásárolták. A gránátposztóhoz szinte elmaradhatatlanul hozzátartozott a színjelzó szederjes szó, ez valószínúleg a hamuszínú posztót jelentette. Az egyes darabok általában anyagban és színárnyalatban eltértek egymástól. A kisznicérposztót a 17. század vége felé már nem említik a források a kelmefajták között, a gránátposztó pedig a 18. század elsô felében túnik el. A szegények abaposztója mellett egyre gyakoribb lesz a karazsia használata, elsôsorban kék, fehér, esetleg zöld színekben. (Bobrovszky, 1980; Papp, 1930:19-20).

A 16. századi magyar férfiviselet fóbb darabjai voltak a nadrág, a dolmány és a mente. A nadrág szúk, testhez szabott volt, kezdetben nem díszítették. Valószínúleg olyan kis rész látszott ki belóle a bôrkapca vagy a csizma szárától a hosszú dolmány széléig, hogy a díszítésnek semmiféle tere nem nyílott (Höllrigl, 1991:357-387). A szolgaféléknél és a kevésbé tehetôs gazdaembereknél kedvelt volt a salavári vagy salavárdi. Ezt a 17. század végéig abaposztóból készíttették a szabókkal, késóbb pedig kék, ritkábban fehér karazsiaposztóból is. A szabócéhek háromféle méretben (öreg, rôfös és singes vagy kis) varrták közösen a nadrágokat és a salavárdikat vásári eladásra, és a hasznon osztoztak. Ezt a nadrágtípust salavárdi-bugyogónak is nevezték, mert bizonyára bôvebb szabású volt, mint az általános szúk formájú nadrág. Valószínúleg kapcás bocskort, sarut vagy bakancsfélét viselhettek hozzá, a szúk magyar nadrághoz pedig csizmát. A salavárdi viselete az ezerhétszázas években kezdett megszúnni. Elnevezése egy újabb nadrágfajtára vándorolt át, amelyet viszont éppen a módosabbak, a gazdák és iparosok viseltek, és egyes vidékeken rajhuzlinak is nevezték (Papp, 1930:23). A források szerint a 18. század végén még viselték a szegényebb rétegek (Bobrovszky, 1980).

A kaftán ráncolatlan, simán esô, hosszú kabát, mely csípóig testhezálló, onnan pedig bokáig bôvül. Ujjai nincsenek vállba szabva, hanem ugyanabból a darabból szabottak, mint a kabát törzse. A hónaljban rendszerint összevarratlanul hagynak egy rést az ujjak alsóvarrásából, ezen ki lehet dugni a karokat, emiatt a kaftán ujjai oldalt üresen maradnak. Elöl középen végig nyitott, nyaktól lefelé a mellen zsinórból való hurkok- 
kal és gombokkal kapcsolható össze. Mint az ábrázolásokból kiderül, a kaftánt nálunk elsôsorban a férfiak használták felsôkabátnak, a dolmány felett (Palotay, 1940).

A dolmányt közvetlenül az ing fölött viselték, mellényfélét nemigen használtak. A dolmány derékig testhezálló, lefelé bôvülő, szúk ujjú köntös, elöl súrú gombsorral. Legrégibb alakjában majdnem bokáig ért. Fô jellegzetességét a keleti kaftánéval azonos szabása adja meg. Kezdetleges alakjában az egész egy darab kelméból készült. A dolmány az idők folyamán egyre inkább megrövidült, a 17. században általában combig ért. Ujja hosszú volt, a kézfejet is betakarta, ezért a végét néha visszahajtották, télen kesztyú helyett is megfelelt. A 17. század közepe tájáról fennmaradtak csonkaujjú dolmányok is (Höllrigl, 1991:357-387).

A dolmány fölött viselt felöltôt a 16. század közepétől általában mentének hívták. Kezdetben hosszabb volt a dolmánynál, hasított ujjú, nem testhez álló köpönyeg volt, széles, a háton lógó sarkos gallérral. Hogy a járást megkönnyítsék, a mente két szárnyát gyakran felhajtva az övbe gyúrték. Írott adataink ezenkívül említik a palástot, a ködmönt, a subát, a kámzsát, a köntöst és a hacukát is (Höllrigl, 1991:357-387). A jobb módúak a mente vékony nyári és a melegebb, bélelt fajtáját is használták. A nyári mentének (és természetesen a nyáron hordott dolmánynak is) vékonyabb kelmébôl, a török idôkben bagazsiából volt a bélése. A téli mentét a szegényebbek bárányboorrel béleltették, és fekete bárányprémet varrattak rá. A jobb módúak többféle vadprémet, elsôsorban rókabőrt használtak e célra. Balla Gergely (1856) és Hornyik János (1861) is visszaemlékezik néhány idôsebb ember abaköpönyegére, ami valószínúleg megegyezik az említett mentével. Ezeket nemcsak abából, hanem jobb minôségú posztóból is készítették, és nemcsak fehér színú, hanem kék, ritkábban fekete változata is ismert (Papp, 1930:26).

A dolmány fölött a 16. században általában szövött sálból való övet viseltek. Ezt elöl csomóba kötötték, de a két vége a dolmány szélénél lejjebb ért. A 17. században feltûnt a zsinórkötegekből készült széles öv is, mely aztán az elôzoot lassan kiszorította. A fehérnemúk közül az ing egyszerú szabású volt, az ujját általában egybeszabták a testrésszel. Zsákformájú volt, és aránylag rövid, többnyire nem ért köldökön alulra. Ujja bô, nyakrészét néha mélyen kivágták, máskor gallért illesztettek rá. A középkori rövid alsónadrág, a berhe szára a 16-17. században majdnem a bokáig meghosszabbodott, alját kirojtozták vagy kivarrták. A 16-17. századi süveg többnyire nemezbôl készült, alakja visszahajtott szélú, lapos tetejú kalapféle volt, elöl gyakran tokba erôsített, kisebb-nagyobb tollal vagy hátrahajló tollbokrétával. Ugyanezt a formát szôrmébôl is készítették. A 17. században ez a nemezsüveg megmagasodott, színe többféle lehetett, de leggyakrabban fekete. A 18. század végéig viselték. (Höllrigl, 1991: 357-387; Papp, 1930:27)

A 16-17. századi magyar férfiviselethez rövid szárú saru vagy törökös csizma (kitûnô bőrből készült, kemény szárú) tartozott. A hódoltság korában nemcsak kész csizmákat hoztak be Törökországból, hanem feldolgozatlan bőröket is. Így nálunk is készült csizma török módra, melyet bevándorolt törökök készítettek, vagy a hazai iparosok tanulták meg az előállítását. A csizma felső részét két darab bőrből szabták, talpa domború volt (Höllrigl, 1991:357-387). A 17. századi Kecskeméten általános volt a csizma 
használata, ahogy ezt a csizmadiák 1656-ban megerôsített szabadalomlevele is mutatja, amely kötelezte a céhet, hogy a város lakóit lássa el szattyánbőrból készített csizmákkal, amennyiben erre nem képesek, török munkájú csizmát kell a városba hozniuk. Anyaga lehetett a szattyánon kívül kordovány vagy karmazsin, színe pedig sárga vagy vörös, de legfớképp fekete (Papp, 1930:28).

Jellegzetes törökös lábbeli a félcipô, amely alatt a lábszárak belsô oldalán fưzôs, boka fölé érô, vékony, puha bőrkapcát viseltek. A töröktôl átvett félcipó és kapca nálunk rövid idố alatt a magyar igényeknek és életviszonyoknak megfelelően alakult át. Mindkét lábbeli általában színes bőrból készült. A török papucs hegyes orra fölfelé kunkorodott, keretelése keskeny volt, hogy a mecset elócsarnokában minél könnyebben letehessék, míg a magyar saru orra legömbölyödött, és keretelése csaknem bokáig ért. Idővel a bôrkapca és a félcipô eggyé olvadt, és belül fưzôs, száraz cipô lett beloole (Höllrigl, 1991:357-387). Bobrovszky Ida a felsorolt lábbeliket a következókkel egészíti ki: saru, gyulai papucs, sólya, szekernye, fülescipellô, szárazcsizma (Bobrovszky, 1980).

A magyar férfiöltözet keleti jellege a hódoltság egész korszakán keresztül megmaradt. 1601-ben Kecskeméten és Kőrösön fosztogatott egy tatár csapat, melyet a város férfilakossága üldözóbe vett, és nemcsak a rablott holmikat, hanem sajátjuk holmijuk egy részét is elvették tőlük. A visszaszerzett öltözetdarabok között találjuk a következôket: „egi vörös kisnitzer dolmán, zöld dolmáni, kék mente, zöld selem üv (öv), egi aranyos szél, pápista bálvány, vörös kopot dolmáni, 3 feir fölsố ruha, egi fekete (ti. sötét) zöld uj carasia mente, egj fekete kék béllet mente, fekete kék uj carasia dolmáni, vörös béllet mente, vörös mente béllet rövid, meztelen ködmen, feir vegh cisnicerök, fölsố ruhák, dolmánok, szöke végh cisnicerök”. Ezt követi még a felsorolásban sok kisznicér dolmány, nadrág, szúr, ing, fehér ruha, tatárok ruhadarabjai mindenütt a „tatár” jelzôvel említve, mint például: „kék tatár dolmán, tatár feir palástok, tatár ingökh, tatár fölsố ruha, egi feir dolmán tatár” és különbözô színú, „feir, fekete, zöld, vörös” tatár menték. Ugyanekkor a mészároslegényeknek egy karazsia ruhát vagy szúrt (szûrchuhat), vagy ködment, továbbá egy sarut, egy „cipellest” ád a város. A városi jegyzók (deákok) javadalmazásában, többek között, „egi carasia dolmán, egi harasnia cisnicer, egi cisnicer nadrágh, saru cipellös” bukkan fel, késôbb egy kisznicér bélelt mentét említenek, és ugyancsak sarut, cipellôst kap a vásárbíró is. Amikor a jegyzô megkapja a ruháját, a török tolmácsnak, Mehemetnek is egy fekete zöld dolmányt, karazsiaposztóból, kisznicér nadrágot és kisznicér harisnyát, valamint „fölsô ruhát” ajándékoznak (Papp, 1930:16).

Az ezerhatszázas években nagy mennyiségú vörös, kék, zöld, ritkábban fehér vagy fekete kisznicér, karazsia, „londis”, néha gránát (szederjes gránát) posztót, ilyen színú és anyagú dolmányt, mentét, nadrágot adnak ajándékul a városban megforduló török, hajdú katonáknak, azok vezéreinek és a török tolmácsoknak. Egyéb ruhaféléket is kaptak: „fölsôruha”, ködmön, különbözó lábbelik: deli csizma, száras csizma, paraszt kapca, jancsár kapca, karmazsinkapca, abakapca (valószínúleg azonos a paraszt kapcával), papucs, cipellős, bocskor, harisnya stb. Ezeket a portékákat nagy mennyiségben küldte a város a földesurak háza népének is. Az említett termékeket a városi boltokban lehetett vásárolni. A ruhadarabok formájában, szabásában nem volt különbség. 1642-ben 
a kecskeméti szappanoscéh privilégiumának artikulusai között szerepel, hogy a gazda tartozik a legénynek egy „kisznicér bélelt dolmánnyal, egy kisznicér bélelt mentével és egy kisznicér nadrággal”.

A hódoltsági közállapotoknak és az egyre szabadabb forgalomnak megfelelóen 1663-ban a kecskeméti városi tanács, az egész lakossággal egyetértésben, felszabadította a kereskedelmet: e szerint minden adófizetô kecskeméti lakos háborítás nélkül hozhatott a városba vagy vihetett ki onnan bármiféle árut, jószágot, tehát ruhaféléket is, mint például szúrt, ködment, dolmányt, nadrágot, söveget és sarut. A szomszédos községekkel kölcsönhatás tapasztalható a viseletben. Kész darabokat nemigen, inkább ruhaanyagokat Budáról, Szegedrôl, Szolnokról vagy török földrôl hoztak. Az országost követô helyi viseletben megtaláljuk a legjellemzőbb ruhadarabokat: a mentét, a dolmányt és a szúk nadrágot. A hódoltság századfordulóján gyakran ugyanabból a kelméből, kisznicérből vagy karazsiából készíttették az öltözet minden darabját, de a szegényebbeknek erre nem volt lehetôségük (Papp, 1930:17).

A viseleti darabok annyira értékesnek számítottak, hogy tételként szerepeltek vételárakban, bérekben, sôt még a végrendeletekben is. A hagyatéki jegyzékek is bôséges adatot nyújtanak a korabeli viseletról. A 16. század második felében Budán és Pesten letelepedố török kereskedôk elsôsorban a mindennapi élethez közel álló, az azt közvetlenül kielégítố iparágakkal foglalkoztak, például ruházati cikkek elóállításával és árusításával (Papp, 1930:19; Gerelyes, 1979:200-216). 1969-ben Budán hunyt el a jómódú Hadzsi Ahmed török mester, aki gyertyaöntéssel foglalkozott. Hagyatéki leltára a következố viseleti darabokat tartalmazta; három darab bogcsával (díszes nagykendó, amibe a ruhanemúket kötötték) rendelkezett. Makrama nevezetú kendôje szintén három darab volt (apró, zsebben hordott kendô). Ezt ajándéktárgyak becsomagolására is használták, esetleg tárgyakat, edényeket vagy kenyeret takartak be vele. Pisgir nevú asztalkendố három darab volt az elhunyt tulajdonában, közülük kettôt jemeninek neveztek a hagyatéki leltárban. Ezek finom anyagból készült, tarka, virágos darabok lehettek. Desztmal nevú törülközóból két darabbal rendelkezett, de ezek nem voltak különösebben értékesek. Mindhárom eddig említett textilféle magyarországi használatáról megemlékeznek a források (Gerelyes, 1979:206).

A korabeli viselet története szempontjából is a hagyatéki összeírások elsôrendú támpontot adnak. Hadzsi Ahmed jegyzékében a következó ruhadarabok szerepelnek: dolama nevú kabátja (változó hosszú, derékig testhez simuló kiskabát) összesen öt darab volt. Sokféle anyagból varrták, az elhunyt hagyatékában két darab, mohair nevú anyagból készült, vastag gyapjúdolamát találunk. Az egyiket télikabátnak nevezi az öszszeíró, a másikról pedig csak azt jegyzi meg, hogy vörös színú. Egy harmadik dolama szuf néven fordul elő, ez kecske- vagy teveszőrből készült anyag volt. A gyertyaöntő legértékesebb kabátja kívül selyem, bélése pedig pamut vagy gyapjú. Egy köpönyeggel is rendelkezett, melyet barani néven írtak össze. Volt még két kiskabátja, ezek mellényszerú ruhadarabok lehettek, nevük zibun. A kabátok alatt alsóruhát vagy inget hordott. A felsoroltakon kívül volt még a tulajdonában egy ing készítéséhez elegendô vászon, illetve egy ing szerepelt, melyet csak fürdőben viselt. Igen értékesnek írják finom selyemanyagból készült övét. Kizárólag otthoni viseletre harisnyákkal rendel- 
kezett, ha kiment az utcára, ezek fölé csizmát húzott. Fejére az arakije-sapka (három darab, ebből egy arannyal átszôtt) fölé desztar nevú turbánkendôt tett az utcai viselet kiegészítéseként. Az arakije-sapka szorosan a fejhez simuló kis sapka volt, melyet a turbán alatt viseltek, vagy bent a lakásban, esetleg hálósapkaként. Hadzsi Ahmed ruhadarabjai közül legértékesebb vörös színú kabátja, amely arannyal átszôtt anyagból készült, ezüstgombokkal díszítve (Gerelyes, 1979:200-216).

Magyar és török hagyatékokban egyaránt nagyon gyakori tétel a feradzse, a dolma vagy dolman, a kebe, a kapanicse és a csaksir. A mezôvárosi polgári hagyatékokban ez utóbbi török nadrágtípus nem szerepel, helyette gyakori a salvar (salavári, salvárdi) a forrásokban. Az aba és csoha anyagnevekkel szintén mindkét fajta hagyatékban találkozhatunk. Mindezek a férfiviseletre vonatkoznak, a török nói viselet darabjai magyar hagyatékban nem fordulnak elô, kivéve a mezôvárosi hagyatékok sûrún emlegetett kürdijét. Bizonyos török ruhadarabok soha nem szerepelnek magyar hagyatékban (hirka, dizlik), illetve a turbán alkotórészei (arakijje, kavuk, desztar) sem. A kaftán ugyan fellelhetô a debreceni magyar hagyatékokban, nyilvánvaló azonban, hogy ebben a formájában magyar viseletté soha sem vált (Gerelyes, 1987:83-93).

A viseleti darabokat kivéve, más török tárgyak használata nem vált általánossá. Az átfedés mellett inkább kettôsségrôl lehet szó, vagyis a kultúrjavak egymás mellett éléséról. A török luxustárgyak használata azonban jellemzó volt a 16-17. században. Ezek lehettek drága szövetek, különféle kelmék, a fôúri hagyatékokban úgy emlegetik óket, mint „török buja ümögöket”, vagy „skófiummal varrott török keszkenôket” (Gerelyes, 1987:88-100).

A leírtak szemléltetésére érdemes felsorolni az elhunyt Mehmed Cselebi 1568. augusztusi hagyatéki leltárának viseleti darabjait: 1 db farkasbunda, 1 vörös színú skarlát esôkabát (jagmurluk), 1 vörös rövid kabát (nimten), 1 vörös skarlát rövid kabát (nimten), 1 kék brokátdolmány, 1 zöld brokátdolmány szôrmével, 1 kék gyapjúdolmány, 1 zöld kasmír rövid kabát szôrmével (nimten), 1 kék nadrág (salvar), 1 kék nadrág (csaksir), 1 fehér kaftán, 1 másik kaftán, 1 ezüstös öv, 1 vörös nadrág, 1 használt kék dolmány, 1 atlaszselyem sapka (kuvuk), 1 jamboli-i rövid köpeny (kebe), 1 fehér rövid köpeny (kebe), 1 vörös atlaszselyem dolmány, 1 használt sapka, 1 sisak, 1 szolgának való esôköpeny, 75 zira karazia posztó, 7 vörös isztamet, 20 magyar vászon, 2 pár csizma, 1 db új turbánkendô, 2 másik turbánkendô, 1 zöld turbánkendô, 1 használt dolmány, 1 fehér jamboli-i rövid köpeny, 1 turbánsapka, 1 használt rókabunda, 1 jamboli-i rövid köpeny (kebe), 1 fehér arakijje sapka, 1 használt selyemszélú sapka, 2 fehér arakijje sapka. Összehasonlításképp érdemes felidézni Nagy Gergely magyar parasztember hagyatékát: 1 db használt prémes csoha, 1 prém, 1 használt ing, 1 használt csizma, 1 kendő (makrama) (Gerelyes, 1987:83-93).

A leírt viselet körülbelül a 18. század végéig maradt meg teljes egészében anélkül, hogy külsố hatások érték volna. Minden magyar városba eljutottak az idegenból jött újítások, amelyek aztán egyes rétegek öltözködését gyökeresen átalakították, mindenesetre egyik viseletfajtában sem maradtak hatás nélkül. Idegen iparosok és kereskedók is egyre többen telepedtek le városainkban, mely természetesen a lakosság öltözködésében is átalakulást eredményezett (Papp, 1930:29-32). 


\section{Nôi VISELET}

A magyar nôi ruha fốbb darabjai a szoknya, a vállfúzô, az ingváll, a kötény, a mente, a kürdi, a zubbony és a köpeny voltak. A nôk ruházkodására vonatkozó elsô kecskeméti viselettörténeti adat szerint, 1598-ban a város szakácsnôjének bérében a következô ruhadarabokat említik: „egj fére valo, 2 elö kötô, egjik gyolcz, egji ködmen, 2 ümögh váll, saru, cipellős”. A török idők közepe táján gyakran jegyezték fel, hogy a földesuraknak, illetve ezek háza népének „patiolatoth”, „vörös végü”, „kék végü”, „sahoss vörös végü”, „fehér sahoss”, „szép aranyos varrott” kendőket, keszkenóket küldtek, kisebbeket és nagyobbakat, amelyeket a kecskemétiek helyben készítettek, így valószínúleg maguk hordtak ilyeneket (Höllrigl, 1991:357-387; Papp, 1930:33).

A ruhaanyagok a következófélék lehettek: félrázsa, gyolcs, atlasz, karton, karazsia, kamuka, kamellott, selyem és bársony. Leggyakrabban vörösból készíttették a szoknyákat. 1766-ban egy kecskeméti vásáron egy szabó tulajdonából elveszett „egy kék kalamasia szoknya, fényes, egészen meg van bélelve, és egy kék egész rása szoknya” (Papp, 1930:36).

A mente anyaga többféle lehetett: kamuka, tafota, tabit, csömörlet és mohér (Höllrigl, 1991:357-387; Bobrovszky, 1980). A mente a 18. század elejétól egyre inkább jellemzô volt a nôk viseletében is. Ezek azonban változatosabb színúek és néha finomabb anyagúak voltak a férfiakénál, és a fémes (arany vagy ezüst) zsinórozás is gyakoribb volt rajtuk (Papp, 1930:37).

A kürdi neve az oszmán-törökból került nyelvünkbe; eredetileg ujjatlan, béleletlen nôi mellényt jelentett. Az átvétel után nálunk bélelték, és prémmel, ezüstkapcsokkal díszítették. Viselése valószínúleg csak a hódoltság idejére volt jellemzô (Höllrigl, 1991:357-387; Bobrovszky, 1980). Az ezerhétszázas évek körül a nôi ruhafélék között többször említették a kürdit. Egy 1680-ból való kecskeméti végrendeletben egymás után sorolják fel a mentét és a kürdit, tehát e kettố nem lehet azonos. Egy szegényebb asszony végrendeletében így szerepel az említett ruhadarab: „Kürdi, zobony mind kapcsaival”, egy 1711-es tanúvallomás pedig a következôket említi, mint egy öltözethez tartozókat: „Szederjes kürdi, szoknya, bársony vállal, ingváll, selyem elôkötô, kendő”. Ez a legkésôbbi adat, amelyben a kürdi neve még előfordul. Papp László felveti, hogy a kürdi esetleg azonos lehetett a férfiak dolmányával, mégis különbözhetett annyira, hogy saját nevet kapott (Papp, 1930:38).

A jobb módú asszonyok öltözetében gyakori volt a köpönyeg, amely bizonyára díszesebb lehetett a férfiakénál. Még a múlt század elsố felében is hordták, az 1826. évi kecskeméti szabóremek „palást” néven kívánja meg elkészítését (Papp, 1930:39). A hideg ellen a nôk a férfiakéhoz hasonló, hasított ujjú köpönyeget vagy kis mentét használtak.

A lábbelik közül a csizmát, a cipellôst és a sarut hordták. A 17. század elejétôl kezdve a csizma volt a legáltalánosabb az asszonyok és lányok viseletében egyaránt (Papp, 1930:42).

A 16-17. században az egyszínú ruhákat kedvelték. A szoknya általában egy „fakórázsa” nevú szövetból készült, ehhez fél sing bársony kellett, ezenkívül aranyperem, 
a szoknya aljára posztó, alája pedig bagazsia. A kendőket a budai törököktől szerezték be (Höllrigl, 1991:357-387; Bobrovszky, 1980).

Balla Gergely a 19. században a következóképpen idézte fel a hódoltságkori asszonyok viseletét: „Az asszonyok majd mindnyájan füles gerezna mentéket kivált hideg idóben viseltenek, patyolatot fejeken fehért hordoztanak, azokat két felól a füleik körül gombos gyönggyel füzött ezüst tükben ékességnek okáért tartottak. Ingvállaikon aranyos formákban két külön felől vallott himeket egyelitvén az időnek akkori alkalmaztatásához képest becsesnek itéltek: akiknek pedig jobb módjok volt benne, ezüstból készitett párta öveket is derekaikon mutogattak. A leányok nyokokon gyöngyöt nem viseltenek, hanem mesterségesen egyben füzött csipkékkel megékesitett fodrokat kötöttenek. Mind asszonyok, mind leányok csizmában jártanak” (Balla, 1856:16-17).

A fentiekben leírt viselettípusokhoz a 18. század második felében kezdtek újabb, idegen formák hozzákapcsolódni. A női öltözködésben valamivel korábban jelentkeztek az újítások, mint a férfiaknál, de hasonló, vegyes átmeneti stíluskorszakot hoztak létre (Papp, 1930:42).

A gyermekek ruházata alig különbözött a felnôttekétôl. Négy-öt éves korig a fiúk és lányok egyforma hosszú köntöskében jártak. Késôbb ruhájuk teljes egészében megegyezett a felnôttekével (Höllrigl, 1991:357-387).

Különféle szabályok írták elô, mely ruhaanyagok, milyen díszek, ékszerek viselése a nemesemberek kiváltsága, ezeket a városi polgárok és parasztemberek nem viselhették. A ruha különböztette meg a társadalom különbözố rétegeit, tette fölismerhetôvé bizonyos tisztségek betöltôit, például a városi tanács tagjait. Az évszázadok folyamán a parasztság sok elemet átvett a nemesi és polgári öltözetből. „Ruha teszi az embert” - ez a szólás az elmúlt századokban nagyon határozott jelentéssel bírt. A ruha megkülönböztette a társadalmi rétegek mellett a különbözó nemzetiségeket is (Flórián, 1980:3). A ruházat, öltözködés vagy viselet alakulását és változását a történelmi tényezôk jelentősen befolyásolták. Minden társadalomnak és történelmi kornak megvolt a divatja, ez pedig hatással volt a népviseletre is. A magyar paraszti viseletek múltját, történetét fơleg a 19. század elejétôl kezdve ismerjük, az azt megelőzó korokról azonban keveset tudunk (Edelényi, 2009:122-123). Annyit mindenesetre igen, hogy a magyarság öltözetét a Kárpát-medencében való letelepedés óta keleti és nyugati hatások érték, melyek közül az egyik legjelentősebb befolyásoló közeg a hódoltság kori török lakosság megjelenése és a helyi társadalomra gyakorolt vizuális effektusa volt.

\section{FELHASZNÁLT IRODALOM}

Balanyi Béla (1968): Kecskemét gazdasági jelentôsége a XVIII. század végéig. In: Kecskemét. Tanulmányok a város múltjáról, jelenérôl. Szerk. Heltai Nándor, Kecskemét Város Tanács, Kecskemét.

Bálint Sándor (1968): A szegedi nép. Gondolat Kiadó, Budapest.

Balla Gergely (1856): Nagykôrösi krónika. Szabó Károly, Szilágyi Sándor, Kecskemét.

B. Bobrovszky Ida (1980): A XVII. századi mezốvárosok iparmúvészete (Kecskemét, Nagykôrös, Debrecen). Akadémiai Kiadó, Budapest.

Domanovszky György (1981): A magyar nép díszítômúvészete I-II. A hódoltság kora. Akadémiai Kiadó, Budapest. 
Edelényi Adél (2009): Népi kultúra. Néprajzi alapismeretek. MMI, Budapest.

Fekete Lajos - Káldy-Nagy Gyula (1962): Budai török számadáskönyvek (1550-1580). Akadémiai Kiadó, Budapest.

Fél Edit - Hofer Tamás - K. Csilléry Klára (1969): A magyar népmúvészet. Corvina Kiadó, Budapest.

Flórián Mária (1980): Magyar népviseletek. Móra Ferenc Kiadó, Budapest.

Gerelyes Ibolya (1979): Török hagyatéki összeírások, mint kultúrtörténeti források. In: Tanulmányok Budapest múltjából XXI. Budapest Történeti Múzeum, Budapest.

Hofer Tamás - Fél Edit (1975): Magyar népmúvészet. Corvina Kiadó, Budapest.

Hornyik János (szerk.) (1861): Kecskemét város története, oklevéltárral II. Kecskemét.

Höllrigl József (1991): Magyar és törökös viseletformák a XVI-XVII. században. In: Magyar múvelôdéstörténet 3. Babits Magyar-Amerikai Kiadó, Szekszárd (reprint).

Novák László (1986): A három város. Gondolat Kiadó, Budapest.

Novák László (1982): Mezốvárosi népmúvészet. Kecskemét, Nagykôrös, Cegléd. Arany János Múzeum, Nagykôrös.

Palotay Gertrud (1940): Oszmán-török elemek a himzésben. Magyar Történeti Múzeum, Budapest

Papp László (1930): A kecskeméti viselet múltja. Néprajzi Értesító, 22. évf., 1. sz., 14-46. old.

Takáts Sándor (1928): A török hódoltság korából. Genius, Budapest. 